CLINICAL STUDY

\title{
Quantitative analysis of somatostatin receptor subtype (SSTR 1-5) gene expression levels in somatotropinomas and non-functioning pituitary adenomas
}

\author{
Giselle F Taboada ${ }^{1}$, Raul M Luque ${ }^{8}$, Wildebranham Bastos ${ }^{5}$, Renata F C Guimarães ${ }^{1}$, Jorge B Marcondes ${ }^{2}$, Leila M \\ $\mathrm{C}_{\text {Chimelli }}{ }^{3}$, Rosita Fontes ${ }^{6,7}$, Paulo J P Mata ${ }^{5}$, Paulo Niemeyer Filho ${ }^{5}$, Denise P Carvalho ${ }^{4}$, Rhonda D Kineman ${ }^{8}$ \\ and Mônica R Gadelha ${ }^{1,7}$ \\ Serviços de ${ }^{1}$ Endocrinologia, ${ }^{2}$ Neurocirurgia, ${ }^{3}$ Anatomia Patológica, Hospital Universitário Clementino Fraga Filho, Rio de Janeiro, Brazil, ${ }^{4}$ Instituto de \\ Biofísica Carlos Chagas Filho, Universidade Federal do Rio de Janeiro, Rio de Janeiro, Brazil, ${ }^{5}$ Serviço de Neurocirurgia do Hospital da Santa Casa de \\ Misericórdia do Rio de Janeiro, Pontifícia Universidade Católica, Rio de Janeiro, Brazil, ${ }^{6}$ Laboratório Diagnósticos da América, Rio de Janeiro, Brazil, \\ ${ }^{7}$ Instituto Estadual de Diabetes e Endocrinologia Luis Capriglione, Rio de Janeiro, Brazil and ${ }^{8}$ Section of Endocrinology and Metabolism, Department of \\ Medicine, University of Illinois at Chicago and Jesse Brown VA Medical Center, Chicago, Illinois, USA
}

(Correspondence should be addressed to M R Gadelha at Rua Nascimento Silva, 555/101 Ipanema, 22421-020 Rio de Janeiro, Brazil; Email: mgadelha@hucff.ufrj.br)

\begin{abstract}
Objective: It is believed that the variable effectiveness of somatostatin analogs in post-surgical management of somatotropinomas and non-functioning pituitary adenomas (NFPA) may be due in part to variable expression of somatostatin receptor isoforms (SSTR1-5), within and between pituitary tumor types.

Design and methods: Quantitative real-time RT-PCR was used to compare absolute mRNA copy numbers for all five SSTR isoforms in 23 somatotropinomas and 19 NFPA.

Results: Somatostatin receptor subtype 5 mRNA was present at the highest level in somatotropinomas, followed by SSTR $2>$ SSTR $3 \gg$ SSTR $1 \gg$ SSTR 4 . In contrast, SSTR 3 mRNA was present at the highest level in NFPA, followed by SSTR2, while SSTR1, SSTR4, and SSTR 5 transcripts were only detectable in select tumors. Among somatotropinomas, a positive correlation was found between SSTR2 mRNA levels and the percent decrease of $\mathrm{GH}(\% \mathrm{GH})$ after 3 and 6 months of therapy with octreotide long acting repeatable (LAR) $(r=0.51$ and $r=0.66 ; P=0.05$ and $P=0.008)$. Also the percent decrease of IGF-I (\%IGF-I) after 3 months of octreotide LAR was negatively correlated with SSTR 5 and \%IGF-I after 6 months of octreotide LAR was positively correlated with SSTR2.

Conclusions: The present report is a large series examining SSTR mRNA levels in somatotropinomas and NFPA. These initial findings suggest that detailed knowledge of the SSTR mRNA expression profile in somatotropinomas can help to predict the hormonal response to therapy with LAR. Also, it appears that SSTR3 in NFPA may be a potential target for SSTR3 preferential or universal ligands such as pasireotide.
\end{abstract}

European Journal of Endocrinology 156 65-74

\section{Introduction}

The most common approach of treating patients with somatotropinomas and non-functioning pituitary adenomas (NFPA) is surgical removal of the tumor, with the primary clinical objective being the reduction of mass effects and preservation of pituitary function (1). For somatotropinomas, an additional treatment goal is to reduce growth hormone $(\mathrm{GH})$ hypersecretion, obtaining biochemical control, defined as random GH levels less than $2.5 \mu \mathrm{g} / \mathrm{l}$, suppression of GH to below $1 \mu \mathrm{g} / \mathrm{l}$ during an oral glucose load and normalization of insulin-like growth factor-I (IGF-I) levels (2). However, surgical 'cure', in acromegaly, occurs in only $50 \%$ of the patients with non-invasive macroadenomas (3-5). Among
NFPA, tumor regrowth has been reported in $25-75 \%$ following craniotomy (6) and 40-50\% after transsphenoidal surgery (TSS) of non-irradiated patients $(7,8)$.

Since surgery alone is frequently not curative, adjuvant medical treatment is often necessary. In acromegaly, the long-acting somatostatin analogs (SA) octreotide and lanreotide are routinely used, and are reported to reduce $\mathrm{GH}$ levels to less than $2.5 \mu \mathrm{g} / \mathrm{l}$ in $56-72 \%$ of the patients, with normalization of IGF-I in $66-75 \%(9,10)$. In addition, a review of studies (11) reporting the effectiveness of SA as a primary medical management of somatotropinomas showed that the response is variable among patient population, where $51 \%$ experience significant tumor shrinkage $(6-92 \%$ of original volume). In contrast to somatotropinomas, the 
majority of NFPA do not respond to the currently available SA, with respect to reduction of tumor size and re-growth following surgery $(12,13)$.

The poor response rate of about one-third of the somatotropinomas and the majority of NFPA to the currently available SA therapy has been attributed to inappropriate expression and/or function of somatostatin receptors (SSTR) (14). Somatostatin receptors are G-protein-coupled receptors, which are encoded by five separate genes (SSTR1-5). All the five genes are expressed in normal adult human pituitaries, however, SSTR 4 mRNA is found at extremely low levels $(15,16)$. Somatostatin receptors expression in pituitary adenomas is reported to be highly variable within and between tumor subtypes (17-33). In studies conducted with non-pituitary tissues, all SSTR subtypes have been shown to have anti-proliferative effects in some cell types and SSTR 2 and SSTR 3 were specifically shown to initiate apoptosis (34). However, the exact SSTR subtypes that are involved in SA-mediated pituitary tumor shrinkage remains to be elucidated. On the other hand, SSTR2 and SSTR 5 are clearly established as the primary inhibitors of GH secretion $(19,35)$. More recently, SSTR1 selective agonists were shown to be effective in suppressing $\mathrm{GH}$ release from $\mathrm{GH}$-secreting pituitary adenomas, in vitro $(22,36)$. The currently used long-acting SA, octreotide, and lanreotide, bind preferentially to SSTR2, with a greater than tenfold lower affinity for SSTR 5 and minimal binding to the other SSTR subtypes (SSTR $3 \gg$ SSTR $1 \gg$ SSTR4) (34). Therefore, the SSTR selectivity of octreotide and lanreotide, coupled with the highly variable expression of SSTR subtypes by pituitary adenomas, may in part explain why only a subset of somatotropinomas and very few NFPA are responsive to the therapeutic actions of the currently available SA. To circumvent this problem, SA with high affinity for SSTR1, SSTR2, SSTR3, and SSTR5 (SOM-230-pasireotide) or with selective specificity for SSTR1 (BIM-23296 and $\mathrm{CH}$ 275) and SSTR5 (BIM-23 206 and BIM-23 268) have been developed and are under investigation for clinical use $(37,38)$.

The majority of studies which have examined SSTR expression patterns in pituitary adenomas have utilized standard RT-PCR techniques, which can only accurately assess whether the receptor is expressed or not $(17,18$, 22-24, 26-29, 31). More recently, quantitative real-time RT-PCR has become available and has been used to assess the absolute levels of SSTR subtypes in somatotropinomas $(19,20,32,36)$ and gonadotropinomas (33). Some of these studies also evaluated the relationship between SSTR1-5 mRNA levels in somatotropinomas and acute in vivo or in vitro response to octreotide (18-21). In the present study, we have developed and applied this same quantitative technique to compare and contrast the SSTR1-5 mRNA levels in somatotropinomas and NFPA. Preliminary studies were also conducted by examining the relationship between SSTR1-5 mRNA copy number in somatotropinomas and the hormonal response to 3- and 6-month post-surgical treatment with octreotide longacting repeatable (LAR).

\section{Subjects and methods}

\section{Subjects}

Tumor tissue samples were obtained from 23 somatotropinomas and 19 NFPA during transsphenoidal surgery. A portion of the tumor was retained for pathological examination and the remaining fragments were snap frozen in liquid nitrogen until RNA extraction or placed in a nucleic acid stabilizing solution (RNA Later, Ambion, Austin, TX, USA) overnight at $4{ }^{\circ} \mathrm{C}$, as specified in the manufacturer's protocol, and then stored in liquid nitrogen until RNA extraction.

Diagnosis of acromegaly was based on the presence of classic clinical features and the lack of GH suppression to $<1 \mu \mathrm{g} / \mathrm{l}$ during an oral glucose tolerance test and/or positive $\mathrm{GH}$ staining of the tumor specimen by immunocytochemistry. One acromegalic patient (no. 3) exhibited prolactin co-secretion as noted by elevated prolactin levels and confirmed by positive immunostaining for prolactin of tumor specimen. Diagnosis of NFPA was based on the presence of a tumor in the sella turcica visualized by magnetic resonance imaging (MRI) or computed tomography (CT) in the absence of symptoms suggesting hormone hypersecretion and biochemical confirmation of normal or hypofunctioning pituitary. Immunocytochemistry revealing negative immunostaining for all anterior pituitary hormones or positive immunostaining for glycoprotein hormones and/or $\beta$ subunit confirmed the diagnosis.

In the acromegalic patients for whom surgery was not curative (defined by the lack of GH suppression to less than $1 \mu \mathrm{g} / \mathrm{l}$ during an oral glucose tolerance test and IGF-I above the upper limit of reference values (ULRV) for age and sex assessed at least 3 months after surgery), medical treatment with octreotide LAR was started with $20 \mathrm{mg}$ at 28 days intervals. After 3 months of therapy, GH and IGF-I levels were assessed on the day of the fourth injection, just before it, and octreotide LAR dose was increased to $30 \mathrm{mg}$ in the next injection if biochemical parameters of acromegaly were not achieved (GH $<2.5 \mu \mathrm{g} / \mathrm{l}$ and normal IGF-I for age and sex). To date, we have complete data on 15 of these patients, including $\mathrm{GH}$ and IGF-I levels at diagnosis, after surgery and 3 and 6 months after beginning medication.

This study was approved by the Ethics Committee of the Hospital Universitário Clementino Fraga Filho and the Institutional Review Board of the UIC and JBVAMC, Chicago. Informed consent was obtained from each patient before the study. 
Selection of primers. All primer sets were selected using genomic sequences obtained from Genbank (National Center for Biotechnology Information (NCBI)) and Primer 3 software (NCBI) with selection parameters set to (i) pick primers that differ by no more than $0.2{ }^{\circ} \mathrm{C}$ in annealing temperature, (ii) exclude primers that may form primer dimers, and (iii) amplify a product of 100-200 bp. Sequences of selected primers were used in BLAST (NCBI) searches to check for potential homology to sequences other than the designated target. The primers, the expected product sizes, annealing temperatures, and Genbank accession numbers are provided in Table 1.

Verification of primer specificity. To verify the primer specificity, each primer set was used in a standard PCR (MRI Fermentas PCR Master Mix-Fermentas, Hanover, MD, USA) to amplify cDNA generated by RT (RT; MRI Fermentas First-Strand Synthesis Kit-Fermentas) using random hexamer priming of total RNA isolated from normal pituitary tissue (obtained during surgery for the resection of a somatotropinoma-histological examination revealed normal tissue). Thermal cycling profile consisted of a pre-incubation step at $95{ }^{\circ} \mathrm{C}$ for $10 \mathrm{~min}$, followed by 35 cycles of denaturation $\left(95^{\circ} \mathrm{C}, 1 \mathrm{~min}\right)$, annealing $\left(61-64{ }^{\circ} \mathrm{C}, 1 \mathrm{~min}\right)$ and extension $\left(72{ }^{\circ} \mathrm{C}\right.$, $1 \mathrm{~min})$. Products were run on an agarose gel and stained with ethidium bromide to confirm that only one band was amplified and no primer dimers formed. An aliquot of the PCR products was then purified using the MinElute PCR Purification kit (Qiagen). Purified PCR products were then sequenced to confirm target specificity. Aliquots of purified PCR products were used to construct standard curves for real-time PCR (see below).

Confirmation of primer efficiency and construction of standard curves - initial screening of primer efficiency was performed using real-time PCR amplifying twofold dilutions of RT products where optimal efficiency was demonstrated by a difference of a CT between dilutions. For real-time PCR, we use the SYBR PCR Master Mix (Bio-Rad). The thermocycling and fluorescence detection were performed using a Stratagene Mx3000p RealTime PCR machine (Stratagene, La Jolla, CA, USA). If preliminary efficiency tests were confirmed, the concentration of purified PCR products were determined using Picogreen DNA quantification kit (Molecular Probes, Eugene, OR, USA) and the PCR products were serial diluted to obtain standards containing $10^{1}, 10^{2}, 10^{3}$, $10^{4}, 10^{5}$, and $10^{6}$ copies of the template per microliter. One microliter of each standard was amplified by realtime and standard curves generated by the Stratagene Mx3000p Software. The $\mathrm{R}^{2}$ values for all standard curves generated ranged between 0.997 and 1.003. Primer sets that yielded efficiencies between 90 and $110 \%$ were accepted, where an efficiency of amplification of $100 \%$ indicates all templates in each cycle are copied. If all validation parameters were met, the selected primers and reaction conditions were used to amplify cDNA from tumor samples.

Quantitative real-time PCR of SSTR subtype cDNA from tumor samples - pituitary tumors were processed for a recovery of total RNA using the Trizol reagent (Life Technologies, Gaithersburg, MD, USA). Total RNA was then purified with the Absolutely RNA kit, with DNAase treatment (Stratagene). The amount of RNA recovered was determined by the Ribogreen RNA quantification kit (Molecular Probes). Total RNA $(1 \mu \mathrm{g})$ was reverse transcribed (RT) in a $20 \mu \mathrm{l}$ volume using the reagents supplied in the cDNA First-Strand Synthesis kit (Fermentas) and cDNA was treated with RNAase $\mathrm{H}$. One microliter aliquots of the resulting cDNA were amplified by real-time PCR using the primers specified above. Thermal cycling profile consisted of a preincubation step at $95^{\circ} \mathrm{C}$ for $10 \mathrm{~min}$, followed by 40 cycles of denaturation $\left(95^{\circ} \mathrm{C}, 30 \mathrm{~s}\right)$, annealing $\left(61-64{ }^{\circ} \mathrm{C}, 1 \mathrm{~min}\right)$, and extension $\left(72{ }^{\circ} \mathrm{C}, 30 \mathrm{~s}\right)$. Total RNA samples that were not reverse-transcribed were run to control for genomic and/or technical DNA

Table 1 Primer sequences, product sizes, annealing temperatures, and GenBank Accession numbers used for quantitative assessment of SSTR1-SSTR5 and housekeeping genes (GAPDH, $\beta$-actin, cyclophillin, and HPRT) by real-time RT-PCR.

\begin{tabular}{|c|c|c|c|c|c|}
\hline & Sense & Anti-sense & $\begin{array}{l}\text { Product } \\
\text { size }(b p)\end{array}$ & $\begin{array}{c}\text { Annealing } \\
\text { temperature } \\
\left({ }^{\circ} \mathrm{C}\right)\end{array}$ & $\begin{array}{c}\text { Genbank } \\
\text { Accession no. }\end{array}$ \\
\hline SSTR1 & САСАTTTCTCATGGGCTTCCT & АСАААСАССАТСАССАССАТС & 165 & 61 & BC035618 \\
\hline SSTR2 $^{\mathrm{a}}$ & GGCATGTTTGACTTTGTGGTG & GTCTCATTCAGCCGGGATTT & 185 & 61 & NM001050 \\
\hline SSTR3 & TGCCTTCTTTGGGCTCTACTT & АTССТССТССТСAGTCTTCTCC & 190 & 61 & NM001051 \\
\hline SSTR4 & CGTGGTCGTCTTTGTGCTCT & AAGGATCGGCGGAAGTTGT & 174 & 63 & BC069063 \\
\hline SSTR5 & CTGGTGTTTGCGGGATGTT & GAAGCTCTGGCGGAAGTTGT & 183 & 61 & NM001053 \\
\hline GAPDH & ААТСССАТСАССАТСТТССА & AAATGAGCCCCAGCCTTC & 122 & 64 & NM002046 \\
\hline$\beta$-actin & АСТСТTCCAGCСTTCСTTССТ & CAGTGATCTCCTTCTGCATCCT & 176 & 64 & NM001101 \\
\hline HPRT & CTGAGGATTTGGAAAGGGTGT & TAATCCAGCAGGTCAGCAAAG & 157 & 61 & BT019350 \\
\hline Cyclophillin & TGGTCTTTGGGAAGGTGAAAG & TGTCCACAGTCGGAAATGGT & 109 & 61 & AF022115 \\
\hline
\end{tabular}

GAPDH, glyceraldehyde-3-phosphate dehydrogenase; HPRT, hypoxanthine ribosyltransferase.

aSSTR2 primers amplify both SSTR2A and SSTR2B isoforms. 
contamination (background). It should be noted that a standard curve was run with each set of samples to estimate copy number. At the end of the amplification, the final product was subjected to graded temperaturedependent dissociation to verify that only one product was amplified. The detection limit of the method is ten copies.

Internal controls. To control for variations in the amount of sample, RNA used in the RT reaction and the efficiency of the RT reaction, the expression level (copy number) of four commonly used housekeeping genes (glyceraldehyde-3-phosphate dehydrogenase-GAPDH, $\beta$-actin, hypoxanthine ribosyltransferase - HPRT and cyclophillin A) was determined for each sample (see Table 1 for primers and annealing temperatures). To determine if these genes were appropriate to use as internal controls, the stability of expression was calculated using the GeNorm 3.3 Visual basic application for Microsoft Excel (http://medgen.ugent.be/ $\sim$ jvdesomp/genorm/) as previously developed and validated by Vandesompele et al. (39). This program calculates the average pairwise variation of a particular gene with all other control genes $(M)$, allowing for the elimination of the worst scoring control genes and recalculation of new $M$ values for the remaining genes. $M$ values $<1.5$ are indicative of a 'stable gene'. The geometric means of copy numbers for the most stable genes are then used as a normalization factor (NF). In our study, calculation of the $M$ values, for the four control genes assessed, revealed that the cyclophillin expression was the least stable $(M=1.7)$. Therefore, $M$ values were recalculated using only GAPDH $(M=$ $0.751), \beta$-actin $(M=0.826)$ and HPRT $(M=1.0420)$ where all values were $<1.5$. Therefore, the geometric means of the copy numbers for these three genes within each sample were used as a NF. Results were then reported as median (minimum-maximum) of SSTR copy number-background/NF.

\section{Statistical analysis}

Comparison of the regression lines generated for each SSTR standard set revealed homogeneity of the regression coefficient, indicating that slopes for each standard curve did not differ (SSTR1, 3.5; SSTR2 3.59; SSTR 3 3.56, SSTR4 3.44, and SSTR5 3.6), thus allowing for the direct comparison of the corrected mRNA copy number of the various SSTR subtypes within tumor type. Mann-Whitney's non-parametric test was used to compare numeric variables between groups. Correlations between numeric variables were studied using the Spearman's correlation test. $P$ values less than 0.05 were considered significant.

\section{Results}

\section{SSTR mRNA content in somatotropinomas}

Fourteen patients were females $(60 \%)$. Median age at diagnosis for the whole group was 40 years (16-62 years). A variable amount of mRNA for each of the five SSTR subtypes was found in somatotropinomas (Table 2), with no significant difference between age and sex. Examination of the relative amount of SSTR mRNA isoforms within individual tumors showed SSTR5 was the dominant SSTR isoform in 52\% (12/ 23 ) of the tumors analyzed (nos 2, 4, 5, 7, 11, 12, 14, $18,19,20,21$, and 22), while SSTR2 mRNA was dominant in $39 \%(9 / 23$; nos $1,3,8,10,13,15,16,17$, and 23; Table 2). In two patients (nos 6, and 9) the predominant mRNA was SSTR3 (Table 2). In sample no. 15, the SSTR mRNA for all SSTR subtypes was low. In this sample, the amount of GAPDH, $\beta$-actin, and HPRT mRNA were comparable with those of the other samples tested (data not shown), indicating that the low copy numbers of SSTR mRNA was not due to RNA degradation or poor RT efficiency.

\section{SSTR mRNA content in NFPA}

Nine patients were females $(47 \%)$. Median age during diagnosis in the whole group was 51 years (18-84 years). A variable amount of the five SSTR subtypes mRNA was also found in NFPA (Table 3), with no significant difference between age and sex. Examination of the medians for normalized values for mRNA of each SSTR subtype revealed that SSTR 3 mRNA exhibited the highest quantity in NFPA, followed by SSTR2, while SSTR1, SSTR4, and SSTR 5 mRNA were only present in select tumors (Table 3). Examination of the SSTR mRNA amount within individual tumors (Table 3) showed SSTR 3 was the dominant isoform in $58 \%(11 / 19)$ of the tumors (nos 1, 2, 3, 4, 7, 8, 9, 10, 12, 13, and 17). In the remaining patients, SSTR2 was dominant in three (nos 6, 18, 19), SSTR1 in three (nos 11, 14, and 16), while the level of SSTR 5 mRNA copies was dominant in one (no. 5). SSTR4 mRNA was low or undetectable in the majority of NFPA samples with the exception of tumors no. 5 and 15 (Table 3).

\section{Comparisons in SSTR mRNA content between somatotropinomas and NFPA}

Overall, somatotropinomas showed higher levels of mRNA for SSTR1, SSTR2, and SSTR 5 compared with NFPA, while the levels of SSTR3 did not differ between tumor types (Fig. 1). SSTR4 levels were not studied in comparisons since median expression among both tumor types was very low, except in select patients (acro no. 12 and NFPA no. 5 and 15; Tables 2 and 3). 
Table 2 SSTR1-5 mRNA levels in individual somatotropinomas; estimated SSTR mRNA copy number corrected by a normalization factor (NF) derived from the expression of three housekeeping genes (HPRT, $\beta$-actin, and GAPDH).

\begin{tabular}{|c|c|c|c|c|c|c|c|}
\hline No. & Age (year) & SSTR1/NF & SSTR2/NF & SSTR3/NF & SSTR4/NF & SSTR5/NF & NF \\
\hline \multicolumn{8}{|l|}{ Females } \\
\hline 1 & 24 & 7 & 10238 & 7 & 0 & 2344 & 2.29 \\
\hline 2 & 26 & 10 & 337 & 66 & 7 & 1779 & 2.94 \\
\hline 3 & 31 & 102 & 3010 & 12 & 37 & 1859 & 0.45 \\
\hline 4 & 31 & 0 & 256 & 77 & 0 & 4170 & 0.54 \\
\hline 5 & 40 & 35 & 173 & 433 & 5 & 2300 & 2.71 \\
\hline 6 & 40 & 412 & 84 & 696 & 54 & 639 & 0.63 \\
\hline 7 & 41 & 29 & 134 & 425 & 5 & 2240 & 1.46 \\
\hline 8 & 42 & 85 & 2976 & 24 & 18 & 2729 & 0.64 \\
\hline 9 & 42 & 16 & 90 & 1226 & 0 & 72 & 1.85 \\
\hline 10 & 45 & 155 & 3873 & 628 & 57 & 3204 & 0.24 \\
\hline 11 & 47 & 21 & 676 & 391 & 3 & 3069 & 0.89 \\
\hline 12 & 48 & 0 & 370 & 217 & 254 & 1385 & 0.23 \\
\hline 13 & 51 & 23 & 2981 & 680 & 0 & 2091 & 0.53 \\
\hline 14 & 59 & 521 & 1060 & 49 & 4 & 2931 & 1.9 \\
\hline Median & 41.5 & 26 & 523 & 304 & 5 & 2270 & 0.76 \\
\hline \multicolumn{8}{|l|}{ Males } \\
\hline 15 & 16 & 23 & 211 & 11 & 1 & 74 & 2.79 \\
\hline 16 & 28 & 450 & 2418 & 6 & 1 & 1799 & 0.62 \\
\hline 17 & 28 & 9 & 8985 & 9 & 1 & 1421 & 3.55 \\
\hline 18 & 30 & 140 & 916 & 308 & 1 & 1763 & 1.25 \\
\hline 19 & 34 & 329 & 1089 & 570 & 1 & 1310 & 2.22 \\
\hline 20 & 38 & 37 & 419 & 892 & 5 & 2394 & 0.72 \\
\hline 21 & 50 & 743 & 983 & 0 & 0 & 2769 & 0.39 \\
\hline 22 & 58 & 184 & 1669 & 248 & 22 & 2460 & 0.36 \\
\hline 23 & 62 & 14 & 2460 & 856 & 2 & 1168 & 3.07 \\
\hline Median & 34 & 140 & 1089 & 248 & 1 & 1763 & 1.25 \\
\hline \multicolumn{8}{|l|}{ All } \\
\hline Median & 40 & 35 & 983 & 248 & 3 & 2091 & 0.89 \\
\hline
\end{tabular}

NF, normalization factor calculated using GeNorm (Vandesompele 2002). GAPDH, glyceraldehyde-3-phosphate dehydrogenase; HPRT, hypoxanthine ribosyltransferase.

Table 3 SSTR1-5 mRNA levels in individual non-functioning pituitary adenomas; estimated SSTR mRNA copy number corrected by a normalization factor (NF) derived from the expression of three housekeeping genes (GAPDH, $\beta$-actin, and HPRT).

\begin{tabular}{|c|c|c|c|c|c|c|c|}
\hline No. & Age (year) & SSTR1/NF & SSTR2/NF & SSTR3/NF & SSTR4/NF & SSTR5/NF & NF \\
\hline \multicolumn{8}{|l|}{ Females } \\
\hline 1 & 18 & 0 & 236 & 755 & 0 & 1 & 1.81 \\
\hline 2 & 33 & 84 & 191 & 406 & 47 & 15 & 1.00 \\
\hline 3 & 43 & 0 & 39 & 642 & 21 & 0 & 1.03 \\
\hline 4 & 47 & 0 & 203 & 420 & 0 & 4 & 0.83 \\
\hline 5 & 48 & 0 & 37 & 56 & 674 & 1417 & 0.66 \\
\hline 6 & 49 & 0 & 382 & 69 & 0 & 7 & 0.75 \\
\hline 7 & 57 & 0 & 74 & 306 & 0 & 7 & 0.62 \\
\hline 8 & 68 & 0 & 12 & 1067 & 0 & 6 & 1.69 \\
\hline 9 & 84 & 0 & 75 & 1218 & 0 & 5 & 0.57 \\
\hline Median & 53 & 0 & 75 & 420 & 0 & 6 & 0.83 \\
\hline \multicolumn{8}{|l|}{ Males } \\
\hline 10 & 31 & 0 & 227 & 496 & 0 & 3 & 0.93 \\
\hline 11 & 40 & 1360 & 34 & 0 & 0 & 112 & 1.72 \\
\hline 12 & 53 & 0 & 30 & 719 & 49 & 5 & 0.46 \\
\hline 13 & 56 & 0 & 208 & 2614 & 0 & 4 & 0.92 \\
\hline 14 & 60 & 139 & 145 & 6 & 0 & 4 & 1.79 \\
\hline 15 & 80 & 0 & 778 & 188 & 874 & 2 & 1.84 \\
\hline 16 & - & 3567 & 0 & 0 & 0 & 2 & 0.47 \\
\hline 17 & - & 79 & 109 & 463 & 9 & 29 & 1.83 \\
\hline 18 & - & 0 & 591 & 31 & 0 & 3 & 1.58 \\
\hline 19 & - & 0 & 310 & 26 & 0 & 4 & 1.18 \\
\hline $\begin{array}{l}\text { Median } \\
\text { All }\end{array}$ & 50.5 & 0 & 177 & 110 & 0 & 4 & 0.93 \\
\hline Median & 51 & 0 & 145 & 406 & 0 & 4 & 1.00 \\
\hline
\end{tabular}

NF, normalization factor calculated using GeNorm (Vandesompele 2002). GAPDH, glyceraldehyde-3-phosphate dehydrogenase; HPRT, hypoxanthine ribosyltransferase. 
A

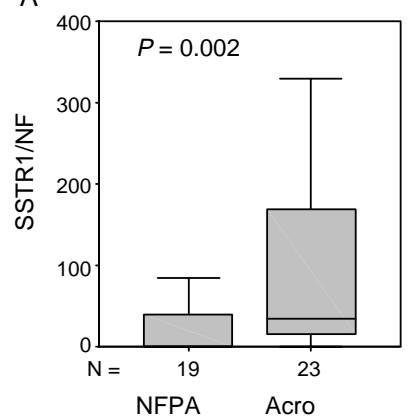

B

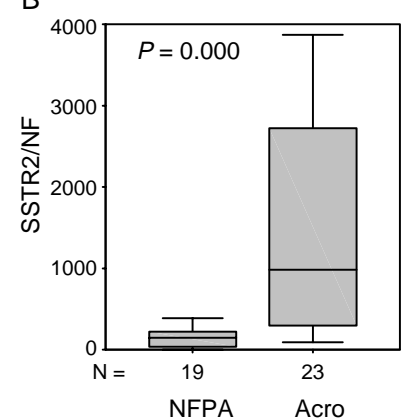

C

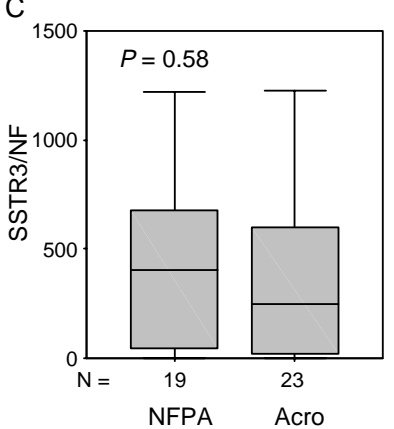

D

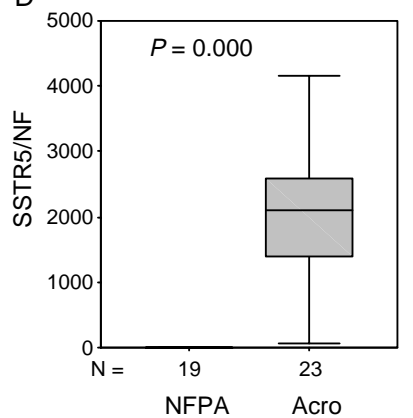

Figure 1 Comparison of SSTR1, 2, 3 and 5 mRNA amount (A to D respectively) between non-functioning pituitary adenomas (NFPA) and somatotropinomas (Acro) corrected for normalization factor (NF). Statistical significance was determined by Mann-Whitney's test. The lower and upper bars represent the first and third quartiles respectively. The line across the box represents median value. The lines above and below the box represent the highest and lowest values, excluding outliers.

Response to treatment with octreotide LAR and correlations with somatotropinoma SSTR 1-5 mRNA copy number

Median GH at diagnosis was $32.2 \mu \mathrm{g} / \mathrm{l}(3.8-420 ; n=$ $20)$ and median GH after surgery was $5.6 \mu \mathrm{g} / \mathrm{l}(2.3-$ $139 ; n=17)$. Median IGF-I after surgery was $191.9 \%$ of the ULRV $(103-616 ; n=17)$. Complete data on 15 of these patients, including GH and IGF-I levels at diagnosis, after surgery and 3 and 6 months after beginning octreotide LAR is presented in Table 4. Median GH at 3 and 6 months were $2.3(0.1-12.9)$ and $2.1(0.1-30.1) \mu \mathrm{g} / \mathrm{l}$ respectively. Median IGF-I at 3 and 6 months were $97.2(36-475.2)$ and 92.0 (22.1692.4) \%ULRV respectively.

A positive correlation was observed between the SSTR2 mRNA levels and the percent decrease of GH (\%GH) after 3 and 6 months of therapy with octreotide LAR $(r=0.51$ and $r=0.66 ; P=0.05$ and $P=0.008$ respectively; Table 5). Also a positive correlation was found between the SSTR2 mRNA levels and the percent decrease of IGF-I (\%IGF-I) after 6 months of therapy with octreotide LAR $(r=0.56 ; P=0.03)$ and a negative correlation was observed between the SSTR 5 mRNA levels and the \%IGF-I after 3 months of therapy with octreotide LAR $(r=-0.67 ; P=0.007$; Table 5). In contrast, there was no significant relationship observed between response to medical therapy and expression levels of SSTR1, SSTR3, and SSTR4 (Table 5).

The median SSTR2 mRNA levels were higher among patients with normalized IGF-I at 6 months of octreotide LAR therapy $(2978 \times 419 ; P=0.01)$. The median SSTR 5 mRNA levels were lower among patients with normalized IGF-I levels at 3 months of octreotide LAR therapy $(1779 \times 2427 ; P=0.03$; Fig. 2). No such differences among SSTR mRNA levels were found among patients with controlled $\mathrm{GH}$ using the criteria of $\mathrm{GH}<2.5 \mu \mathrm{g} / \mathrm{l}$ or the more strict criteria of $1 \mu \mathrm{g} / \mathrm{l}$.

Table 4 Hormonal levels at diagnosis, after surgery and 3 and 6 month treatment with octreotide LAR in acromegalic patients.

\begin{tabular}{|c|c|c|c|c|c|c|c|c|c|c|c|c|c|}
\hline \multirow[b]{2}{*}{ No. } & \multirow[b]{2}{*}{$\begin{array}{c}\text { Age } \\
\text { (year) }\end{array}$} & \multirow[b]{2}{*}{ Sex } & \multirow{2}{*}{$\begin{array}{c}\text { At diag- } \\
\text { nosis } \\
\text { GH }\end{array}$} & \multicolumn{2}{|c|}{ After surgery } & \multicolumn{4}{|c|}{ After 3 months of LAR } & \multicolumn{4}{|c|}{ After 6 months of LAR } \\
\hline & & & & $\mathrm{GH}$ & $\begin{array}{c}\text { \%ULRV } \\
\text { IGF-I }\end{array}$ & $\mathrm{GH}$ & $\begin{array}{c}\% \mathrm{GH} \\
\text { decrease }\end{array}$ & $\begin{array}{c}\text { \%ULRV } \\
\text { IGF-I }\end{array}$ & $\begin{array}{c}\% \text { IGF-I } \\
\text { decrease }\end{array}$ & $\mathrm{GH}$ & $\begin{array}{c}\% \mathrm{GH} \\
\text { decrease }\end{array}$ & $\begin{array}{c}\text { \%ULRV } \\
\text { IGF-I }\end{array}$ & $\begin{array}{l}\% \text { IGF-I } \\
\text { decrease }\end{array}$ \\
\hline 1 & 24 & $\mathrm{~F}$ & 86.3 & 139 & 151.4 & 4.5 & 96.8 & 147.2 & 2.8 & 6 & 95.7 & 99 & 34.6 \\
\hline 2 & 26 & $\mathrm{~F}$ & 9.2 & 5.7 & 110.6 & 2 & 64.9 & 93.4 & 15.6 & 2.9 & 49.5 & 59.3 & 46.4 \\
\hline 3 & 31 & $\mathrm{~F}$ & 25.7 & 3.2 & 103 & 0.1 & 95.6 & 38.9 & 62.2 & 0.1 & 96.9 & 22.1 & 78.5 \\
\hline 5 & 40 & $\mathrm{~F}$ & 35.2 & 6.8 & 221.9 & 5.4 & 20.6 & 160 & 27.9 & 3.5 & 48.5 & 208.9 & 5.9 \\
\hline 8 & 42 & $\mathrm{~F}$ & 51.3 & 10.3 & 171.2 & 3.3 & 68 & 49 & 71.4 & 2.7 & 73.8 & 64.7 & 62.2 \\
\hline 10 & 45 & $\mathrm{~F}$ & 14.1 & 4.2 & 144.8 & 4.2 & 0 & 144.8 & 0 & 0.5 & 88.1 & 73.2 & 49.4 \\
\hline 11 & 47 & $\mathrm{~F}$ & 35.2 & 5.4 & 136.6 & 4 & 26.5 & 475.2 & -247.9 & 4.7 & 13.6 & 692.4 & -406.9 \\
\hline 12 & 48 & $\mathrm{~F}$ & 8 & 2.3 & 197.3 & 2.5 & -7.3 & 145.2 & 26.4 & 2.3 & 1.3 & 232.6 & -17.9 \\
\hline 13 & 51 & $\mathrm{~F}$ & 77 & 2.5 & 276.3 & 0.7 & 72 & 75.6 & 72.6 & 0.2 & 92.8 & 52.3 & 81.1 \\
\hline 16 & 28 & $\mathrm{M}$ & 26.5 & 5.7 & 190.9 & 0.6 & 88.8 & 53.4 & 72 & 1.7 & 70.2 & 95.5 & 50 \\
\hline 19 & 34 & $\mathrm{M}$ & 92.9 & 21.3 & 209.5 & 0.8 & 96.1 & 58.3 & 72.2 & 1.9 & 70.5 & 97 & 53.7 \\
\hline 20 & 38 & $\mathrm{M}$ & 120 & 112 & 137 & 12.9 & 88.5 & 293.3 & -114.1 & 30.1 & 91.1 & 289.9 & -111.6 \\
\hline 21 & 50 & $\mathrm{M}$ & - & 7.3 & 277.5 & 3 & 58.9 & 266.7 & 3.9 & 2.5 & 73.1 & 221.3 & 20.3 \\
\hline 22 & 58 & $\mathrm{M}$ & 6.8 & 2.8 & 193 & 0.2 & 91.8 & 101 & 47.7 & 1.8 & 65.8 & 91.8 & 54.2 \\
\hline 23 & 62 & $\mathrm{M}$ & 127 & 36 & 300.4 & 1.4 & 96.1 & 52.9 & 82.4 & 0.9 & 97.5 & 72.4 & 75.9 \\
\hline
\end{tabular}

$\mathrm{GH}$ in $\mu \mathrm{g} /$; ULRV, upper limit of the reference values; LAR, octreotide long acting repeatable. 
Table 5 Correlations between the mRNA content for each SSTR subtypes and growth hormone (GH) levels at diagnosis and percent decrease in GH and insulin-like growth factor-I (IGF-I) levels after 3 and 6 months of therapy with octreotide LAR.

\begin{tabular}{|c|c|c|c|c|c|}
\hline & \multicolumn{3}{|c|}{ After 3 months with octreotide LAR } & \multicolumn{2}{|c|}{ After 6 months with octreotide LAR } \\
\hline & $\begin{array}{l}\text { GHat diagnosis } \\
(n=20)\end{array}$ & $\begin{array}{c}\% \text { GH decrease } \\
(n=15)\end{array}$ & $\begin{array}{c}\% \text { IGF-I decrease } \\
(n=15)\end{array}$ & $\begin{array}{c}\% \text { GH decrease } \\
(n=15)\end{array}$ & $\begin{array}{c}\% \text { IGF-I decrease } \\
(n=15)\end{array}$ \\
\hline \multicolumn{6}{|l|}{ SSTR1 } \\
\hline$r$ & -0.76 & 0.02 & 0.02 & 0.11 & 0.23 \\
\hline$P$ & 0.75 & 0.94 & 0.9 & 0.7 & 0.41 \\
\hline \multicolumn{6}{|l|}{ SSTR2 } \\
\hline$r$ & 0.18 & 0.51 & 0.26 & 0.66 & 0.56 \\
\hline$P$ & 0.45 & $0.05^{\star}$ & 0.35 & $0.008^{*}$ & $0.03^{*}$ \\
\hline \multicolumn{6}{|l|}{ SSTR3 } \\
\hline$r$ & 0.14 & -0.05 & 0.11 & 0.14 & 0.05 \\
\hline$P$ & 0.57 & 0.87 & 0.69 & 0.61 & 0.87 \\
\hline \multicolumn{6}{|l|}{ SSTR4 } \\
\hline$r$ & -0.37 & -0.41 & -0.17 & -0.29 & -0.02 \\
\hline$P$ & 0.12 & 0.12 & 0.55 & 0.29 & 0.95 \\
\hline \multicolumn{6}{|l|}{ SSTR5 } \\
\hline$r$ & -0.36 & -0.41 & -0.67 & -0.26 & -0.31 \\
\hline$P$ & 0.12 & 0.13 & $0.007^{\star}$ & 0.35 & 0.25 \\
\hline
\end{tabular}

Statistical significance was determined by Spearman's correlation test. *Significant $P$ Value.

\section{Discussion}

To date, this is the largest series examining SSTR1-5 mRNA levels in somatotropinomas and NFPA and it is the first study to compare the corrected mRNA copy numbers of mRNA for all SSTR subtypes between the tumor types. We report that SSTR5 is the dominant SSTR subtype in $52 \%$ of the somatotropinomas tested; while in 39\%, SSTR 2 mRNA levels were dominant. The current results support and extend the early findings of several groups, which used relative or quantitative realtime PCR and found SSTR 5 to be dominant in the majority of the somatotropinomas tested (17-20, 32).

Given the affinity of the long-acting SA, octreotide and lanreotide is above tenfold higher for SSTR2 than for SSTR $5(40,41)$, it is expected that patients with tumors expressing higher levels of SSTR2 would respond more favorably to the available SA therapies.
In fact, a positive correlation was found between the SSTR2 levels and the percent decrease of GH after a 3and 6-month and that of IGF-I decrease after a 6-month course of octreotide LAR. Consistent with these findings, several authors described that tumors removed from patients resistant to octreotide therapy tended to have lower levels of SSTR 2 mRNA $(18,19,21)$. On the other hand, in the current study, the percent decrease in IGF-I levels after a 3-month course of octreotide LAR negatively correlated to SSTR 5 levels. This may be due to the fact that tumors expressing high levels of SSTR 5 tended to express low levels of SSTR2 (although a negative correlation between these SSTR subtypes did not reach statistical significance - data not shown). On the other hand, the percent decrease in IGF-I levels after a 6-month course of octreotide LAR did not correlate with SSTR 5 levels and this finding may be due to the size of the studied sample. Taken together, these reports

A

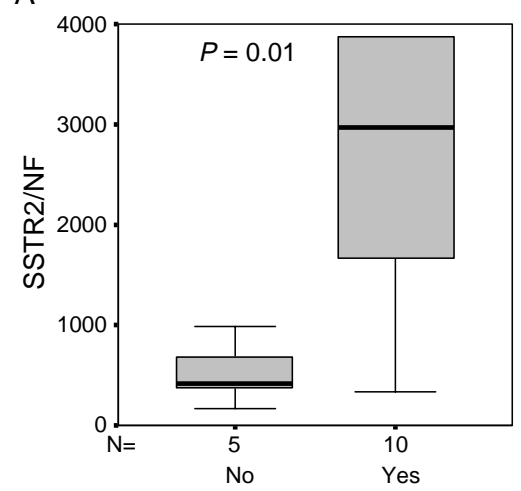

Normalized IGF-I after 6 months of LAR

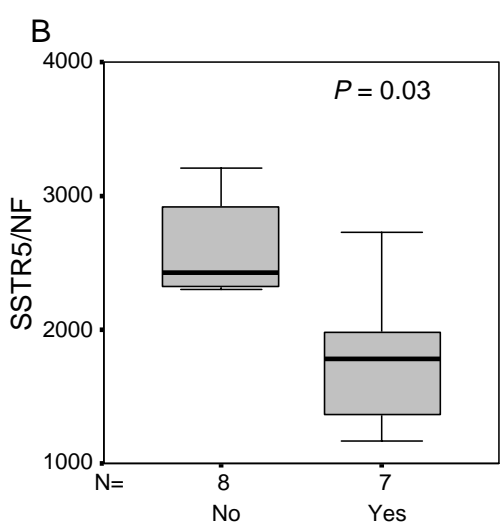

Normalized IGF-I after 3 months of LAR
Figure 2 Comparison of SSTR2 and 5 mRNA copy numbers ( $A$ and $B$ respectively) between patients with normalized IGF-I after a 3 and 6-month course of octreotide long acting repeatable (LAR) therapy corrected for normalization factor (NF). Statistical significance was determined by Mann-Whitney's test. The lower and upper bars represent the first and third quartiles respectively. The line across the box represents median value. The lines above and below the box represent the highest and lowest values, excluding outliers. 
suggest the absolute levels of both SSTR2 and SSTR 5 mRNA may be critical for the maximal GH and IGF-I suppressive effects of octreotide.

In the current report, we observed that NFPA, in contrast to somatotropinomas, expressed relatively low or undetectable levels of SSTR1, SSTR2 and SSTR5. Given the likely role of SSTR2 and SSTR 5 in mediating the antiproliferative actions of octreotide and lanreotide $(21,22,36,42)$, the limited expression of these receptors in NFPA may explain the relative insensitivity of NFPA to the antiproliferative actions of the current SA therapies (24). However, it should be noted that in the current study, select NFPA did express SSTR1 (nos. 11 and 16), SSTR2 (nos. 15 and 18) and SSTR 5 (no. 5) at levels higher than or within the range of somatotropinomas and therefore this small subset of tumors may be responsive to octreotide/lanreotide, as has been reported by a few authors $(24,43)$ or they may respond to SSTR1 and SSTR 5 selective agonists.

Despite the low levels of SSTR1, SSTR2, and SSTR 5 mRNA content, NFPA content of SSTR3 mRNA was comparable to that observed in somatotropinomas, where SSTR 3 mRNA was dominant in $56 \%$ of the NFPA examined. These observations are consistent with the findings of some groups $(17,33)$ and in contrast to others $(26,27)$. These discrepancies may be related to the methodology used (real-time PCR vs relative RT-PCR) more than to the population studied.

Nonetheless, the predominance of SSTR 3 mRNA in NFPA is intriguing and may be advantageous in targeting medical therapies to reduce mass effects. The importance of SSTR3 in mediating ligand-stimulated cell death was first elucidated by Sharma et al. (44), who reported that transfection of CHO cells with SSTR3 exclusively conferred somatostatin apoptotic activity. If ligand activation of SSTR3 mediates similar apoptotic pathways in pituitary cells, we might predict from our current observations that a large portion of NFPA (those that express functional levels of SSTR3) may regress in response to the selective SSTR3 agonists; this may also be the case for a subset of somatotropinomas. Therefore, the recent development of pasireotide, a SA that binds with high affinity to SSTR3, as well as SSTR1, SSTR2, and SSTR 5 may prove to be an effective clinical tool in managing the growth of NFPA, as well as somatotropinomas.

The potential to select and predict the outcome of post-surgical medical management by prescreening tumors for functional SSTR has long been a clinical goal. Targeted selection of the most appropriate SA would not only improve clinical outcome (reduction in hormone secretion and tumor mass), but may also be useful in reducing side effects (16). However, in vitro data $(21,35)$ strongly suggest that the maximal effect of SA treatment likely requires activation of multiple receptors that signal through distinct pathways which can interact to evoke synergistic effects. Therefore, in the analysis of SSTR, one should consider not only the level of each SSTR but also the relationship between of the SSTR isoforms. The true predictive value of the present type of analysis will require a large sample population with detailed clinical follow-up to assess the effectiveness of surgical and medical management; however, the results of this preliminary work are encouraging. To date, such comparisons have only been made in small sample populations $(19,20,32,33$, 36). Therefore to this end, our laboratory is continuing to collect outcome data on the available patients recruited for the present study and are also recruiting additional patients in order to confirm the findings that SSTR 2 and SSTR 5 mRNA content of somatotropinomas will be useful predictors of the subsequent response to SA therapy.

In summary, this report assesses the mRNA levels of all five SSTR subtypes in somatotropinomas and nonfunctioning pituitary adenomas by qRT-PCR, and it is the first series to compare the expression levels of each receptor between the tumor types. Our results also indicate that the hormonal response to octreotide in patients with somatotropinomas is positively correlated to SSTR 2 and negatively correlated to SSTR 5 mRNA levels, suggesting that the assessment of SSTR expression profiles by qRT-PCR may represent an effective screening tool to predict the outcome of postsurgical medical management of somatotropinomas. Also, it appears that SSTR3 in NFPA may be a potential target for SSTR 3 preferential or universal ligands such as pasireotide.

\section{Acknowledgements}

This work is supported by grants from Coordenação de Aperfeiçoamento de Pessoal de Nível Superior (CAPES) (to GFT), Consejeria de Educacion y Ciencia de la Junta de Andalucia (to RML), Fundação de Amparo a Pesquisa do Estado do Rio de Janeiro (to RFCG), Conselho Nacional de Desenvolvimento Científico e Tecnológico (CNPq) (to MRG), NIDDK 30677 (to RDK) and Novartis Pharmaceuticals.

\section{References}

1 Mortini P, Losa M, Barzaghi R, Boari N \& Giovanelli M. Results of transsphenoidal surgery in a large series of patients with pituitary adenoma. Neurosurgery $2005 \mathbf{5 6} 1222-1233$.

2 Giustina A, Barkan A, Casanueva FF, Cavagnini F, Frohman L, Ho K, Veldhuis J, Wass J, Von Werder K \& Melmed S. Criteria for cure of acromegaly: a consensus statement. Journal of Clinical Endocrinology and Metabolism 200085 526-529.

3 Ahmed S, Elsheikh M, Page RCL, Adams CBT \& Wass JAH. Outcome of transsphenoidal surgery for acromegaly and its relationship to surgical experience. Clinical Endocrinology 1999 50 561-567.

4 Gittoes NJL, Sheppard MC, Johnson AP \& Stewart PM. Outcome of surgery for acromegaly - the experience of a dedicated pituitary surgeon. Quarterly Journal of Medicine 199992 741-745. 
5 Sheaves R, Jenkins P, Blackburn P, Huneidi AH, Afshar F, Medbak S, Grossman AB, Besser GM \& Wass JA. Outcome of transsphenoidal surgery for acromegaly using strict criteria for surgical cure. Clinical Endocrinology $1996 \mathbf{4 5} 407-413$.

6 Turner HE, Stratton IM, Byrne JV, Adams CBT \& Wass JAH. Audit of selected patients with nonfunctioning pituitary adenomas treated without irradiation -a follow-up study. Clinical Endocrinology 199951 281-284.

7 Comtois R, Beauregard H, Somma M, Serri O, Aris-Jilwan N \& Hardy J. The clinical and endocrine outcome to transsphenoidal microsurgery of nonsecreting pituitary adenomas. Cancer 199168 860-866.

8 Gittoes NJL, Bates AS, Tse W, Bullivan B, Sheppard MC, Clayton RN \& Stewart PM. Radiotherapy for nonfunctioning pituitary tumours. Clinical Endocrinology $1998 \mathbf{4 8} 331-337$.

9 Freda PU. Somatostatin analogs in acromegaly. Journal of Clinical Endocrinology and Metabolism 200287 3013-3018.

10 Cozzi R, Attanasio R, Montini M, Pagani G, Lasio G, Lodrini S, Barausse M, Albizzi M, Dallabonzana D \& Pedroncelli AM. Fouryear treatment with octreotide-long-acting repeatable in 110 acromegalic patients: predictive value of short-term results? Journal of Clinical Endocrinology and Metabolism $2003 \mathbf{8 8}$ 3090-3098.

11 Bevan JS. The antitumoral effects of somatostatin analog therapy in acromegaly. Journal of Clinical Endocrinology and Metabolism $2005901856-1863$.

12 Katznelson L, Oppenheim DS, Coughlin JF, Kliman B, Schoenfeld DA \& Klibanski A. Chronic somatostatin analog administration in patients with alpha-subunit-secreting pituitary tumors. Journal of Clinical Endocrinology and Metabolism 199275 1318-1325.

13 Plockinger U, Reichel M, Fett U, Saeger W \& Quabbe HJ Preoperative octreotide treatment of growth hormone-secreting and clinically nonfunctioning pituitary macroadenomas: effect on tumor volume and lack of correlation with immunohistochemistry and somatostatin receptor scintigraphy. Journal of Clinical Endocrinology and Metabolism 199479 1416-1423.

14 Hofland LJ \& Lamberts SW. Somatostatin receptors in pituitary function, diagnosis and therapy. Frontiers of Hormone Research 200432 235-252.

15 Patel Y. Somatostatin and its receptor family. Frontiers in Neuroendocrinology 199920 157-198.

16 van der Hoek J, Hofland LJ \& Lamberts SW. Novel subtype specific and universal somatostatin analogues: clinical potential and pitfalls. Current Pharmaceutical Design 200511 1573-1592.

17 Greenman Y \& Melmed S. Expression of three somatostatin receptor subtypes in pituitary adenomas: evidence for preferential SSTR 5 expression in the mammosomatotroph lineage. Journal of Clinical Endocrinology and Metabolism 1994 79 724-729.

18 Corbetta S, Ballaré E, Mantovani G, Lania A, Losa M, Di Blasio AM \& Spada A. Somatostatin receptor subtype 2 and 5 in human GH-secreting pituitary adenomas: analysis of gene sequence and mRNA expression. European Journal of Clinical Investigation 2001 31 208-214.

19 Jaquet P, Saveanu A, Gunz G, Fina F, Zamora AJ, Grino M, Culler MD, Moreau JP, Enjalbert A \& Ouafik LH. Human somatostatin receptor subtypes in acromegaly: distinct patterns of messenger ribonucleic acid expression and hormone suppression identify different tumoral phenotypes. Journal of Clinical Endocrinology and Metabolism 200085 781-792.

20 Park C, Yang I, Woo J, Kim S, Kim J, Kim Y, Sohn S, Kim E, Lee M, Park H, Jung J \& Park S. Somatostatin (SRIF) receptor subtype 2 and 5 gene expression in growth hormone-secreting pituitary adenomas: the relationship with endogenous SRIF activity and response to octreotide. Endocrine Journal $200451227-236$.

21 Saveanu A, Gunz G, Dufour H, Caron P, Fina F, Ouafik L, Culler MD, Moreau JP, Enjalbert A \& Jaquet P. BIM-23244, a somatostatin receptor subtype 2 and 5 selective analog with enhanced efficacy in supressing growth hormone $(\mathrm{GH})$ from octreotide-resistant human GH-secreting adenomas. Journal of Clinical Endocrinology and Metabolism 2001 86 140-145.
22 Matrone C, Pivonello R, Colao A, Cappabianca P, Cavallo LM, Del Basso De Caro ML, Taylor JE, Culler MD, Lombardi G, Di Renzo GF \& Annunziato L. Expression and function of somatostatin receptor subtype 1 in human growth hormone secreting pituitary tumors deriving from patients partially responsive or resistant to longterm treatment with somatostatin analogs. Neuroendocrinology 200479 142-148.

23 Florio T, Thellung S, Corsaro A, Bocca L, Arena S, Pattarozzi A, Villa V, Massa A, Diana F, Schettini D, Barbieri F, Ravetti JL, Spaziante R, Giusti M \& Schettini G. Characterization of the intracellular mechanisms mediating somatostatin and lanreotide inhibition of DNA synthesis and growth hormone release from dispersed human GH-secreting pituitary adenoma cells in vitro. Clinical Endocrinology 200359 115-128.

24 Florio T, Thellung S, Arena S, Corsaro A, Spaziante R, Gussoni G, Acuto G, Giusti M, Giordano G \& Schettini G. Somatostatin and its analog lanreotide inhibit the proliferation of dispersed human non-functioning pituitary adenoma cells in vitro. European Journal of Endocrinology 1999141 396-408.

25 Danila DC, Haidar JNS, Zhang X, Katznelson L, Culler MD \& Klibanski A. Somatostatin receptor-specific analogs: effects on cell proliferation and growth hormone secretion in human somatotroph tumors. Journal of Clinical Endocrinology and Metabolism $2001862976-2981$.

26 Nielsen S, Mellemkjaer S, Rasmussen LM, Ledet T, Astrup J, Weeke J \& Jorgensen JOL. Gene transcription of receptors for growth hormone-releasing peptide and somatostatin in human pituitary adenomas. Journal of Clinical Endocrinology and Metabolism 199883 2997-3000.

27 Miller GM, Alexander JM, Bikkal HA, Katznelson L, Zervas NT \& Klibanski A. Somatostatin receptor subtype gene expression in pituitary adenomas. Journal of Clinical Endocrinology and Metabolism $1995 \mathbf{8 0} 1386-1392$.

28 Panetta R \& Patel YC. Expression of mRNA for all five human somatostatin receptors (hSSTR1-5) in pituitary tumors. Life Sciences 199556 333-342.

29 Murabe H, Shimatsu A, Ihara C, Mizuta H, Nakamura Y, Nagata I, Kikuchi H \& Nakao K. Expression of somatostatin receptor (SSTR) subtypes in pituitary adenomas: quantitative analysis of SSTR2 mRNA by reverse transcription-polymerase chain reaction. Journal of Endocrinology $1996 \mathbf{8} 605-610$.

30 Nielsen S, Mellemkjaer S, Rasmussen LM, Ledet T, Olsen N, BojsenMoller M, Astrup J, Weeke J \& Jorgensen JO. Expression of somatostatin receptors on human pituitary adenomas in vivo and ex vivo. Journal of Endocrinological Investigation 2001 24 430-437.

31 Greenman Y \& Melmed S. Heterogeneous expression of two somatostatin receptor subtypes in pituitary tumors. Journal of Clinical Endocrinology and Metabolism 199478 398-403.

32 Hofland LJ, van der Hoek J, van Koetsveld PM, de Herder WW, Waaijers M, Sprij-Mooij D, Bruns C, Weckenbecker G, Feelders R, van der Lely A-J, Beckers A \& Lamberts SWJ. The novel somatostatin analog SOM230 is a potent inhibitor of hormone release by growth hormone-and prolactin-secreting pituitary adenomas in vitro. Journal of Clinical Endocrinology and Metabolism 200489 1577-1585.

33 Saveanu A, Morange-Ramos I, Gunz G, Dufour H, Enjalbert A \& Jaquet P. A luteinizing hormone-, alpha-subunit-and prolactinsecreting pituitary adenoma responsive to somatostatin analogs: in vivo and in vitro studies. European Journal of Endocrinology 2001 $14535-41$.

34 Olias G, Viollet C, Kusserow H, Epelbaum J \& Meyerhof W. Regulation and fuction of somatostatin receptors. Journal of Neurochemistry 200489 1057-1091.

35 Shimon I, Yan X, Taylor JE, Weiss MH, Culler MD \& Melmed S. Somatostatin receptor (SSTR) subtype-selective analogues differentially suppress in vitro growth hormone and prolactin in human pituitary adenomas. Novel potential therapy for functional pituitary tumors. Journal of Clinical Investigation $1997 \mathbf{1 0 0}$ 2386-2392.

36 Zatelli MC, Piccin D, Tagliati F, Ambrosio MR, Margutti A, Padovani R, Scanarini M, Culler MD \& degli Uberti EC. 
Somatostatin receptor subtype 1 selective activation in human growth hormone $(\mathrm{GH})$-and prolactin (PRL)-secreting pituitary adenomas: effects on cell viability, GH, and PRL secretion. Journal of Clinical Endocrinology and Metabolism $2003 \mathbf{8 8} 2797-2802$.

37 Boerlin V, van der Hoek J, Beglinger CH, Poon KW, Hartmann S, Dutreix C, Kovarik JM, Bruns CH, Weckbecker G, Lewis I, Schnieper P, Hofland LJ \& Lamberts SW. New insights on SOM230, a universal somatostatin receptor ligand. Journal of Endocrinological Investigation 200326 14-16.

38 Hannon JP, Nunn C, Stolz B, Bruns C, Weckbecker G, Lewis I, Troxler T, Hurth K \& Hoyer D. Drug design at peptide receptors: somatostatin receptor ligands. Journal of Molecular Neuroscience $20021815-27$.

39 Vandesompele J, De Preter K, Pattyn F, Poppe B, Van Roy N, De Paepe A \& Speleman F. Accurate normalization of real-time quantitative RT-PCR data by geometric averaging of multiple internal control genes. Genome Biology 20023 1-12.

40 Raynor K, Murphy WA, Coy DH, Taylor JE, Moreau JP, Yasuda K, Bell GI \& Reisine T. Cloned somatostatin receptors: identification of subtype-selective peptides and demonstration of high affinity binding of linear peptides. Molecular Pharmacology $1993 \mathbf{4 3}$ 838-844.
41 Raynor K, O’Carroll AM, Kong H, Yasuda K, Mahan LC, Bell GI \& Reisine T. Characterization of cloned somatostatin receptors SSTR4 and SSTR5. Molecular Pharmacology 199344 385-392.

42 Ren SG, Taylor J, Dong J, Yu R, Culler MD \& Melmed S. Functional association of somatostatin receptor subtypes 2 and 5 in inhibiting human growth hormone secretion. Journal of Clinical Endocrinology and Metabolism $2003 \mathbf{8 8} 4239-4245$.

43 De Bruin TWA, Kwekkeboom DJ, Van't Verlaat JW, Reubi JC, Krenning EP, Lamberts SWJ \& Croughs RJM. Clinically nonfunctioning pituitary adenoma and octreotide response to long term high dose treatment, and studies in vitro. Journal of Clinical Endocrinology and Metabolism 199275 1310-1317.

44 Sharma K, Patel YC \& Srikant CB. Subtype selective induction of p53-dependent apoptosis but not cell cycle arrest by human somatostatin receptor 3. Molecular Endocrinology $1996 \mathbf{1 0}$ $1688-1696$.

Received 6 June 2006

Accepted 10 October 2006 